\title{
Recyclable hypervalent-iodine-mediated solid-phase peptide synthesis and cyclic peptide synthesis
}

\author{
Dan Liu, Ya-Li Guo, Jin Qu and Chi Zhang*
}

\author{
Full Research Paper \\ Address: \\ State Key Laboratory of Elemento-Organic Chemistry, Collaborative \\ Innovation Center of Chemical Science and Engineering (Tianjin), \\ College of Chemistry, Nankai University, Tianjin 300071, China \\ Email: \\ Chi Zhang* - zhangchi@nankai.edu.cn \\ * Corresponding author \\ Keywords: \\ cyclic peptide; FPID; hypervalent iodine(III) reagent; recyclable; \\ solid-phase peptide synthesis (SPPS)
}

Beilstein J. Org. Chem. 2018, 14, 1112-1119.

doi:10.3762/bjoc. 14.97

Received: 14 February 2018

Accepted: 27 April 2018

Published: 22 May 2018

This article is part of the Thematic Series "Hypervalent iodine chemistry in organic synthesis".

Guest Editor: T. Wirth

(C) 2018 Liu et al.; licensee Beilstein-Institut.

License and terms: see end of document.

\begin{abstract}
The system of the hypervalent iodine(III) reagent FPID and $\left(4-\mathrm{MeOC}_{6} \mathrm{H}_{4}\right)_{3} \mathrm{P}$ was successfully applied to solid-phase peptide synthesis and cyclic peptide synthesis. Four peptides with biological activities were synthesized through SPPS and the bioactive cyclic heptapeptide pseudostellarin D was obtained via solution-phase peptide synthesis. It is worth noting that FPID can be readily regenerated after the peptide coupling reaction.
\end{abstract}

\section{Introduction}

The amide bond is one of the most fundamental functional groups in organic chemistry, and it plays a crucial role in the elaboration and composition of biological systems. Amide bonds are widely present not only in peptides and proteins but also in pharmaceuticals and many natural products. Among the methods for amide bond formation, the direct condensation of carboxylic acids and amines in the presence of a coupling reagent is the most convenient and simplest way [1-6]. The most commonly used coupling reagents such as carbodiimide [7], phosphonium [8], and uronium salts [9] are efficient and commercially available. In spite of these merits of traditional coupling reagents, it is still far from ideal because large amounts of chemical wastes are produced during the amide bond formation reaction using these reagents and the coupling reagents cannot be regenerated [10]. Thus, methods for the peptide synthesis which are efficient and atom-economic are still needed.

Hypervalent iodine reagents have drawn researchers' considerable attentions due to their versatile reactivity, low toxicity, ready availability, environmental friendliness, and regenerability [11-27]. Our group has dedicated to the peptide synthesis mediated by hypervalent iodine(III) reagents in recent years. In 2012, for the first time, we reported that the hypervalent 
iodine(III) reagent iodosodilactone (Figure 1) can serve as a condensing reagent to promote esterification, macrolactonization, amidation and peptide coupling reactions in the presence of $\mathrm{PPh}_{3}$ [28]. In addition, the peptide coupling reaction proceeds without racemization in the absence of a racemization suppressant and iodosodilactone can be readily regenerated after the reaction. In order to further enhance the reactivity of iodosodilactone, we designed and synthesized a new derivative of iodosodilactone 6-(3,5-bis(trifluoromethyl)phenyl)- $1 \mathrm{H}, 4 \mathrm{H}$ $2 \mathrm{a} \lambda^{3}$-ioda-2,3-dioxacyclopenta[hi]indene-1,4-dione (abbreviated as FPID, Figure 1) [29].<smiles>O=C1OI2OC(=O)c3cccc1c32</smiles>

iodosodilactone<smiles>O=C1OI2OC(=O)c3cc(-c4cc(C(F)(F)F)cc(C(F)(F)F)c4)cc1c32</smiles>

FPID
Figure 1: lodosodilactone and FPID.

In combination with tris(4-methoxyphenyl)phosphine [(4$\left.\mathrm{MeOC}_{6} \mathrm{H}_{4}\right)_{3} \mathrm{P}$ ], FPID can efficiently mediate peptide coupling reactions within 30 minutes to obtain various dipeptides from standard amino acids as well as sterically hindered amino acids. Moreover, a pentapeptide Leu-enkephalin is successfully synthesized in its protected form using this coupling system. Similar to iodosodilactone, FPID can be easily regenerated after the reaction. The mechanism for this FPID-mediated amide bond formation reaction was proposed with the acyloxyphosphonium intermediate B being the key intermediate (Scheme 1). Herein, as part of our continuing exploration of the application of FPID in peptide synthesis, we disclose its successful application in solid-phase peptide synthesis and cyclic peptide synthesis.

\section{Results and Discussion}

At the beginning of our study, we tried to utilize the system of FPID/(4- $\left.\mathrm{MeOC}_{6} \mathrm{H}_{4}\right)_{3} \mathrm{P}$ in the solid-phase peptide synthesis (SPPS). SPPS has been widely employed in peptide synthesis since its first report by Merrifield in 1963 [30,31]. Compared with classical solution-phase peptide synthesis, the fast development of SPPS is mainly due to its short reaction time, high efficiency, low racemization, simple work-up and automation. In recent decades, various strategies, for example, native chemical ligation (NCL) [32] and serine/threonine ligation (STL) [33], have been reported to solve the problems occurred during the development of SPPS. Peptide synthesis in solution mediated by $\mathrm{FPID} /\left(4-\mathrm{MeOC}_{6} \mathrm{H}_{4}\right)_{3} \mathrm{P}$ is rapid (within $30 \mathrm{~min}$ ) and efficient, at the same time the reactions proceed without racemization.

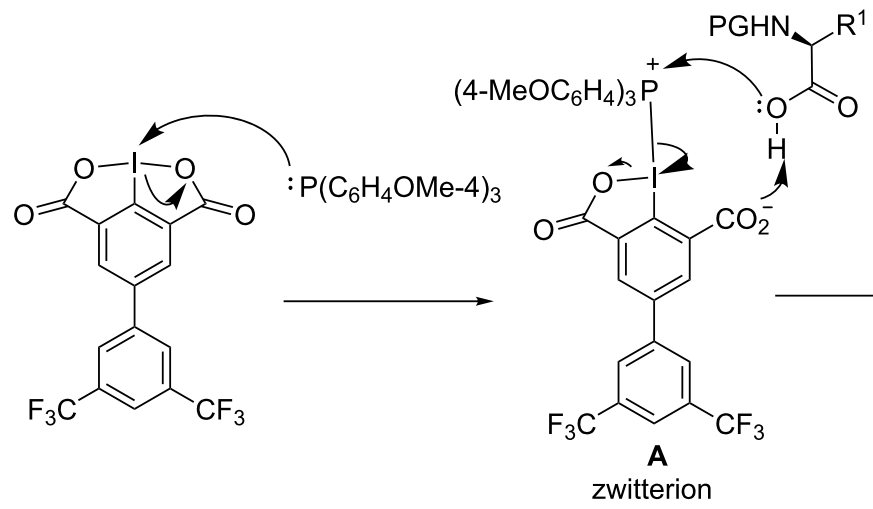

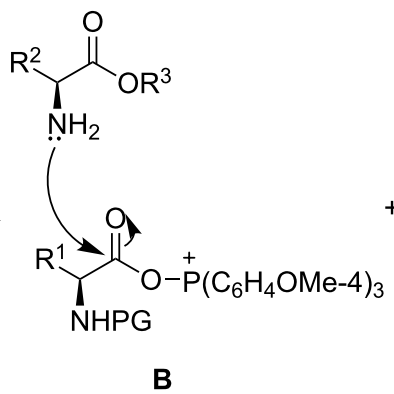<smiles>O=C(O)c1cc(-c2cc(C(=O)O)c(I)c(C(=O)O)c2)cc(C(F)(F)F)c1</smiles>

acyloxyphosphonium

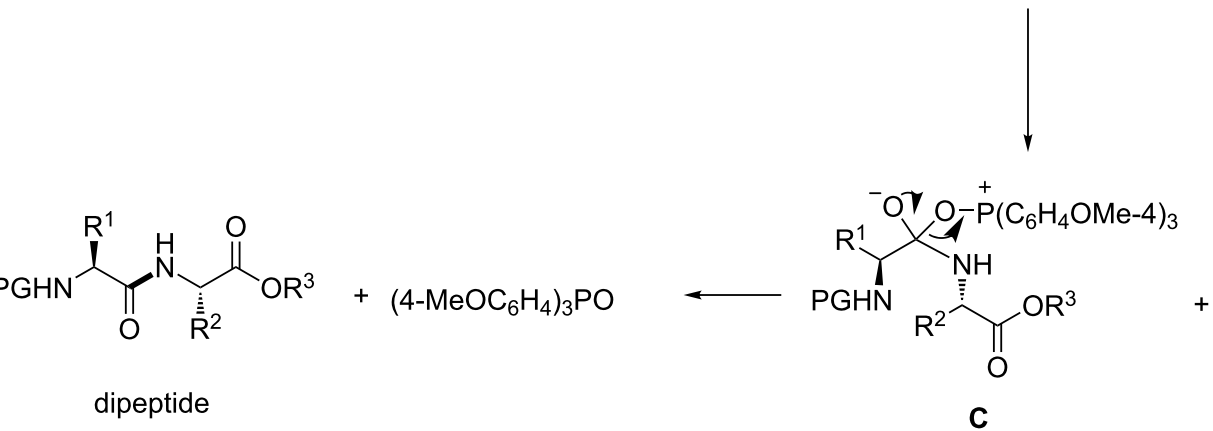<smiles>O=C(O)c1cc(-c2cc(C(=O)O)c(I)c(C(F)(F)F)c2)cc(C(F)(F)F)c1</smiles> 
Thus, it is possible and significant to test whether the FPID/(4$\left.\mathrm{MeOC}_{6} \mathrm{H}_{4}\right)_{3} \mathrm{P}$ system can be used in SPPS.

We selected the commercially available 2-chlorotrityl chloride resin (2-Cl-Trt-Cl resin) as the solid support and [(9-fluorenylmethyl)oxy]carbonyl (Fmoc) as the $\alpha$-amino protecting group The peptides were synthesized following the route as shown in Scheme 2. The C-terminal amino acid was immobilized onto the 2-Cl-Trt-Cl resin in the presence of 3.0 equiv of DIPEA in DCM/DMF (v:v 1:1). Subsequent peptide chain elongation was completed via Fmoc-SPPS protocol, which includes deprotection with $20 \%$ piperidine/DMF and peptide coupling with 3.0 equiv of Fmoc-protected amino acids, 3.0 equiv of FPID, 3.0 equiv of $\left(4-\mathrm{MeOC}_{6} \mathrm{H}_{4}\right)_{3} \mathrm{P}$ and 3.0 equiv of TEA in DMF. After chain elongation and deprotection of Fmoc, the resulting resins were treated with $0.5 \% \mathrm{TFA} / \mathrm{DCM}$ to give the N,Cunprotected peptides as final products. The peptides were purified by reversed-phase HPLC (RP-HPLC).

For the target peptides, we aimed at peptides with specific biological activities. Leu-enkephalin, which is isolated from pig brains, acts as an endogenous mediator at central morphine receptor sites and thus possesses potent opiate agonist activity [34-36]. Leu-enkephalin 1 (Table 1, entry 1) could be successfully synthesized following the route mentioned above (Scheme 2). Besides, the precursor 2 of a cyclic heptapeptide pseudostellarin D [37-39] was also obtained via SPPS in good yield (Table 1, entry 2), the cyclization of 2 to give pseudostellarin D using FPID/(4- $\left.\mathrm{MeOC}_{6} \mathrm{H}_{4}\right)_{3} \mathrm{P}$ will be described in the following part. Moreover, angiotensin I converting enzyme (ACE) inhibitory peptides, widely exist in plants and animals, can serve as potential antihypertensive pharmaceuticals [40-42].
The synthesis of two ACE inhibitory peptides proceeded smoothly in moderate yield (Table 1, entries 3 and 4). Notably, it is unnecessary to protect the hydroxy group of serine, threonine, or tyrosine in advance in the synthesis of these four peptides. The presence of an unprotected hydroxy group does not affect the coupling efficiency, which is consistent with peptide coupling in solution phase [29]. The HRMS spectra of these peptides are consistent with their molecular formula.

\begin{tabular}{|c|c|c|}
\hline entry & peptide & yield \\
\hline 1 & $\mathrm{H}_{2} \mathrm{~N}$-Tyr-Gly-Gly-Phe-Leu-OH (1) & $42 \%$ \\
\hline 2 & $\mathrm{H}_{2} \mathrm{~N}-\mathrm{Gly}$-Gly-Tyr-Pro-Leu-lle-Leu-OH (2) & $53 \%$ \\
\hline 3 & $\mathrm{H}_{2} \mathrm{~N}$-Lys-Leu-Pro-Ala-Gly-Thr-Leu-Phe-OH (3) & $30 \%$ \\
\hline 4 & $\mathrm{H}_{2} \mathrm{~N}-\mathrm{Trp}$-Val-Pro-Ser-Val-Tyr-OH (4) & $21 \%$ \\
\hline
\end{tabular}

Similar to the solution-phase peptide synthesis, FPID can be easily regenerated after SPPS (Scheme 3). After completion of peptide elongation, the washing solution of peptide coupling in each cycle was collected and evaporated. Then the mixture was acidified with $3 \mathrm{~N} \mathrm{HCl}$ and extracted with EtOAc, dried and concentrated in vacuo. The synthetic precursor of FPID 6 could be purified by flash chromatography in order to remove excess Fmoc-protected amino acids during the peptide coupling. Compound 6 was subsequently oxidized with $\mathrm{NaOCl} / \mathrm{HCl}$ to obtain FPID in $90 \%$ yield.

Cyclic peptides, an important kind of peptides, possess several favorable properties such as target selectivity, good binding affinity and low toxicity, which make them attractive candi-
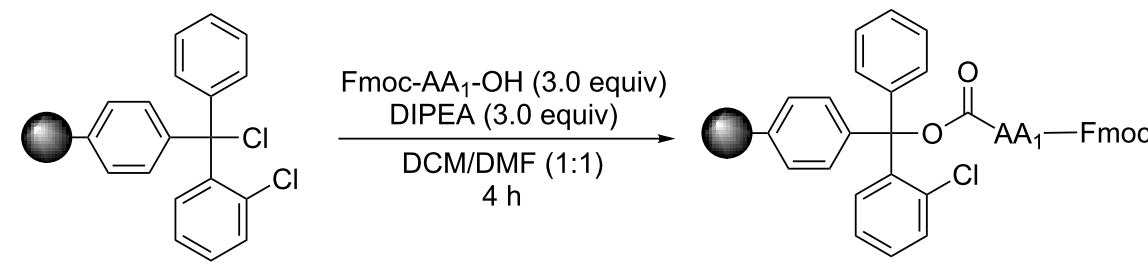

2-Cl-Trt-Cl resin

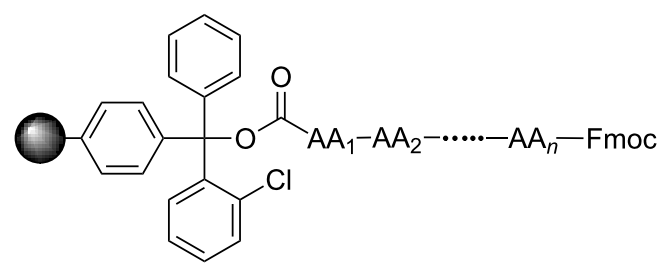

Fmoc-SPPS

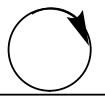

1. $20 \%$ pipedine/DMF, $30 \mathrm{~min}$

2. $\mathrm{Fmoc}-\mathrm{AA}_{n}-\mathrm{OH}$ (3.0 equiv) $\left(4-\mathrm{MeOC}_{6} \mathrm{H}_{4}\right)_{3} \mathrm{P}$ (3.0 equiv) FPID (3.0 equiv) TEA (3.0 equiv) DMF, 1-2 h

1. $20 \%$ pipedine/DMF, $30 \mathrm{~min}$ 2. $0.5 \% \mathrm{TFA} / \mathrm{DCM}, 10 \mathrm{~min}$

Scheme 2: Solid-phase peptide synthesis mediated by FPID/(4- $\left.\mathrm{MeOC}_{6} \mathrm{H}_{4}\right)_{3} \mathrm{P}$. Conditions: The resin loading for 2-Cl-Trt-Cl resin is $0.98 \mathrm{mmol} / \mathrm{g}$. For each peptide synthesized through SPPS, $200 \mathrm{mg}$ 2-Cl-Trt-Cl resin was used. Fmoc-Ser-OH, Fmoc-Thr-OH, Fmoc-Tyr-OH, Fmoc-Trp-OH were directly used without any protecting group on $\mathrm{OH}$ or $\mathrm{NH}$. During the synthesis of 3, Fmoc-Lys(Boc)-OH was used. 


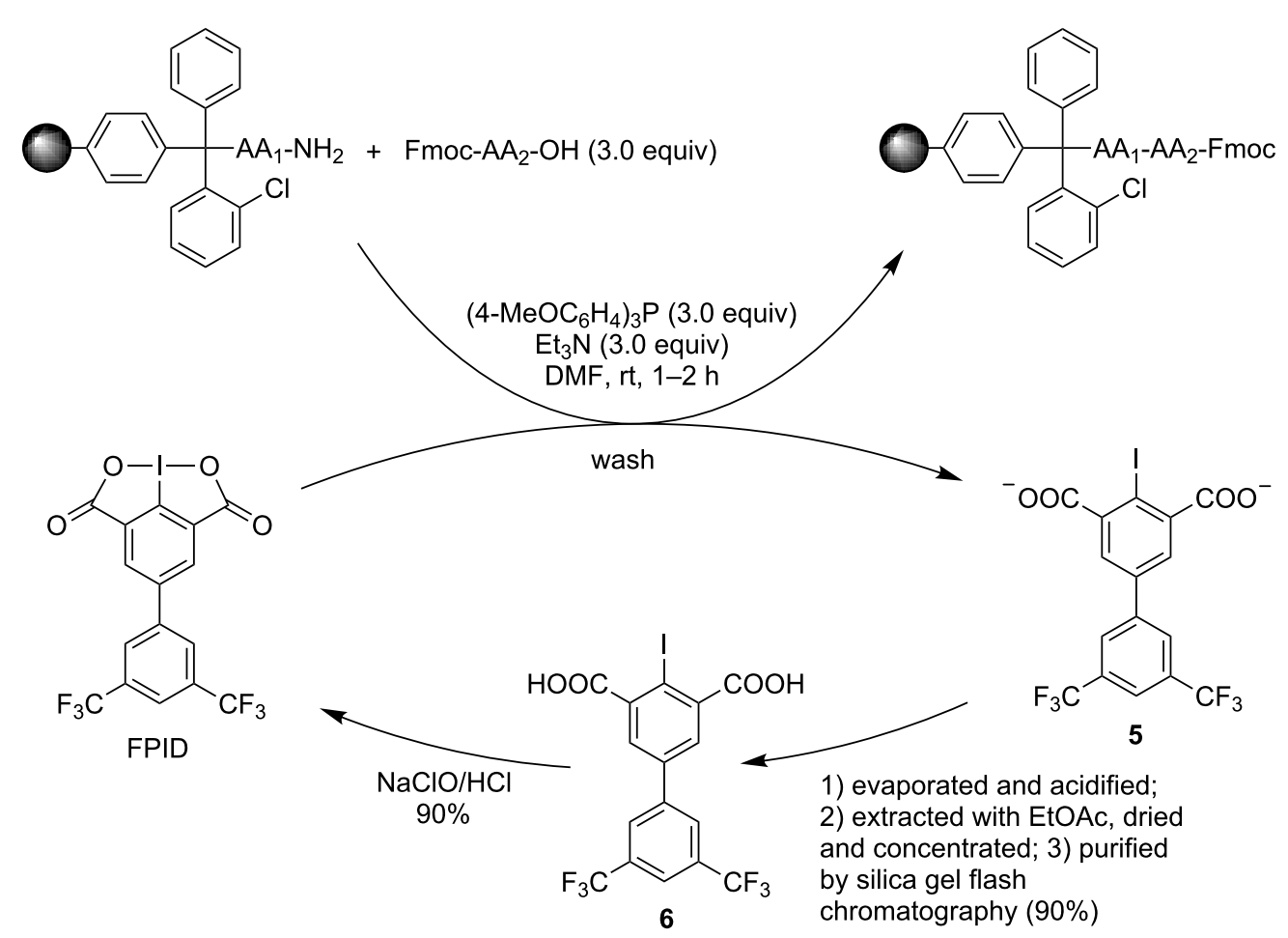

Scheme 3: The regeneration of FPID after SPPS.

dates in the development of therapeutics [43,44]. Due to the particular significance of cyclic peptides, chemists pay considerable attention to the efficient synthesis of cyclic peptides [45]. In the second part of the investigation of the synthetic utility of the FPID/(4-MeOC $\left.{ }_{6} \mathrm{H}_{4}\right)_{3} \mathrm{P}$ system, we tested this system in the cyclic peptide synthesis.

The roots of Pseudostellaria heterophylla are well-known traditional Chinese medicine, which are often used as a lung and spleen tonic. There are more than 10 cyclic peptides isolated from it, for example, pseudostellarin $\mathrm{A}-\mathrm{H}$ and heterophyllin A-D [37,46-49]. Cyclo(Gly-Gly-Tyr-Pro-Leu-Ile-Leu), a cyclic heptapeptide named pseudostellarin D (Figure 2), is one of these cyclic peptides. Pseudostellarin D was first isolated and identified in 1994 by Itokawa and co-workers [37]. In addition, the authors reported that pseudostellarin D showed potent tyrosinase inhibitory activities. In 1999, Belagali and co-workers further evaluated the antimicrobial, antiinflammatory and anthelmintic activities of pseudostellarin D [38]. As for the synthesis of pseudostellarin D, the existing methods utilized the active ester method to complete the cyclization of the linear peptide precursor with the same amino acid sequence of Gly-Gly-Tyr-Pro-Leu-Ile-Leu as a result of the amide bond between "Gly-Leu" being the cyclization position. The first one was reported by Belagali in 1999, pseudostellarin D was obtained by the cyclization of the linear heptapeptide
peptide-PNP ester, which is known as the $p$-nitrophenyl ester method (Scheme 4, method A). The other one was described by Agrigento and co-workers, the cyclization was completed via the $p$-chlorophenyl thioester method with peptide-thioester being the precursor (Scheme 4, method B) [39]. Herein, we realized the synthesis of pseudostellarin D following the same cyclization strategy mentioned above by direct coupling of the precursor 2 without any protecting group utilizing the system of FPID/(4- $\left.\mathrm{MeOC}_{6} \mathrm{H}_{4}\right)_{3} \mathrm{P}$ (Scheme 4, method C).

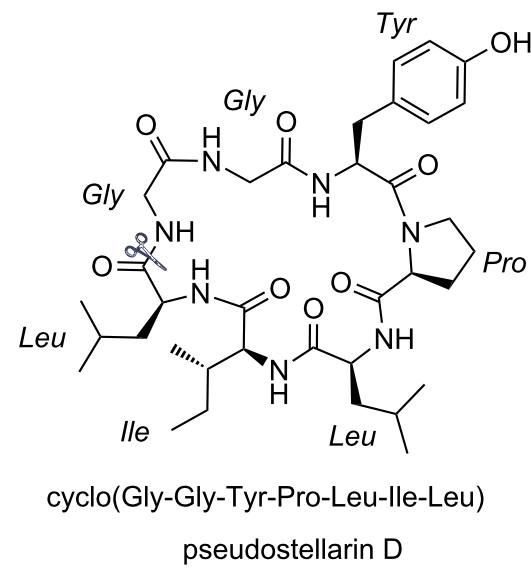

Figure 2: Structure of pseudostellarin D. 


\section{previous methods}

A) Boc-Gly-Gly-Tyr-Pro-Leu-Ile-Leu-OMe

1) $\mathrm{CF}_{3} \mathrm{COOH} / \mathrm{CHCl}_{3}$ $1 \mathrm{~h}, \mathrm{rt}$

2) $\mathrm{CHCl}_{3}$, pyridine

$10 \mathrm{~d}, 0^{\circ} \mathrm{C}$

$76 \%$ over 4 steps

B) $\mathrm{H}$-Gly-Gly-Tyr-Pro-Leu-Ile-Leu-SC ${ }_{6} \mathrm{H}_{4}-\mathrm{Cl}$
1) $\mathrm{LiOH}$ (1.5 equiv)

$\mathrm{THF} / \mathrm{H}_{2} \mathrm{O}(1: 1)$

$1 \mathrm{~h}, \mathrm{rt}$

2) $p$-nitrophenol (2 equiv)

$\mathrm{DCC}$ ( 1.5 equiv)

$\mathrm{CHCl}_{3}, 12 \mathrm{~h}, \mathrm{rt}$

cyclo(Gly-Gly-Tyr-Pro-Leu-lle-Leu)

pseudostellarin D

\section{DMSO $(5 \mathrm{mM})$ \\ $25^{\circ} \mathrm{C}, 24 \mathrm{~h}, 45 \%$ \\ cyclo(Gly-Gly-Tyr-Pro-Leu-lle-Leu) \\ pseudostellarin $D$}

\section{this work}

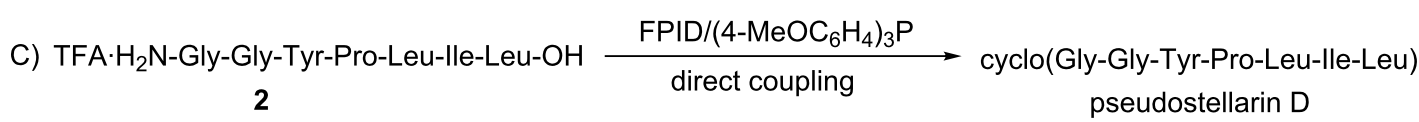

Scheme 4: Synthetic strategies of pseudostellarin D.

We have obtained the precursor 2 through SPPS mediated by FPID/(4- $\left.\mathrm{MeOC}_{6} \mathrm{H}_{4}\right)_{3} \mathrm{P}$ system (Table 1, entry 2$)$. Firstly, the C-terminal amino acid Leu was immobilized onto 2-Cl-Trt-Cl resin. Then the chain elongation was completed by the deprotection of Fmoc and coupling with Fmoc-protected Ile, Leu, Pro, Tyr, Gly, Gly in turn. The successive deprotection of Fmoc, cleavage from the resin and purification via RP-HPLC yielded the precursor 2 (see Supporting Information File 1). Alternatively, the synthesis of the precursor 2 can be achieved through a convergent $[3+4]$ segment condensation strategy in solution phase (Scheme 5). Notably, during the synthesis of tetrapeptide segment 10, the stepwise manner was adopted in order to avoid racemization. In the synthesis of tripeptide segment 13, our condensing system, FPID/(4- $\left.\mathrm{MeOC}_{6} \mathrm{H}_{4}\right)_{3} \mathrm{P}$ was utilized. Besides, the coupling between $\mathbf{1 0}$ and $\mathbf{1 3}$ to yield heptapeptide segment 14 was carried out using 3-(diethoxyphosphoryloxy)-1,2,3-benzotriazin-4(3H)-one (DEPBT) as coupling reagent, which was developed by Ye's group in order to reduce racemization and side reactions [50]. The precursor 2 was obtained via successive deprotection of the C-terminal and the N-terminal protecting group of $\mathbf{1 4}$. The overall yield of this route is $28 \%$.

With the precursor 2 in hand, we then investigated the reaction conditions of its cyclization. Considering the solubility of $\mathbf{2}$ and FPID, we chose DMF as the solvent. At the beginning of our investigation, the reaction was carried out under air within $10 \mathrm{~h}$, we tested the influence of the adding sequence of TEA, FPID and $\left(4-\mathrm{MeOC}_{6} \mathrm{H}_{4}\right)_{3} \mathrm{P}$, and the results indicated that adding TEA first and FPID/(4- $\left.\mathrm{MeOC}_{6} \mathrm{H}_{4}\right)_{3} \mathrm{P} 5$ minutes later performed better than the inverse sequence (Table 2, entries 1 and 2). When prolonging the reaction time to $24 \mathrm{~h}$, the product was obtained in a yield of $23 \%$ and $25 \%$ according to different adding sequence of TEA and FPID/(4-MeOC $\left.{ }_{6} \mathrm{H}_{4}\right)_{3} \mathrm{P}$, and the effect of the adding sequence was the same with that mentioned above (Table 2, entries 3 and 4). Then the reaction was run under $\mathrm{N}_{2}$ atmosphere instead of air, the cyclization yield increased to $27 \%$ (Table 2, entry 5 ). Increasing the equivalents of FPID and (4- $\left.\mathrm{MeOC}_{6} \mathrm{H}_{4}\right)_{3} \mathrm{P}$ to 2.0 equiv resulted in $33 \%$ NMR yield of the product (Table 2, entry 7). Ye's group disclosed that adding univalent metal ions such as $\mathrm{Na}^{+}, \mathrm{K}^{+}$and $\mathrm{Cs}^{+}$to the reaction system for the synthesis of some cyclic pentapeptides and heptapeptide would not only enhance the cyclization yields but also the cyclization rates [51]. Inspired by this finding, we tried to add some metal chlorides into the reaction, such as $\mathrm{LiCl}$, $\mathrm{NaCl}, \mathrm{KCl}, \mathrm{CsCl}$ (Table 2, entries 8-11). The results indicated that adding $\mathrm{NaCl}, \mathrm{KCl}, \mathrm{CsCl}$ could increase the cyclization yield, whereas $\mathrm{LiCl}$ decreased the yield. Among the efficient metal chlorides, adding 5 equiv of $\mathrm{CsCl}$ to the reaction yielded the product in $44 \%$ NMR yield. The isolated yield of pseudostellarin D under the optimized reaction conditions was $32 \%$.

Consequently, pseudostellarin D can be successfully synthesized in $32 \%$ isolated yield ( $44 \%$ NMR yield) under the optimized conditions: FPID ( 2 equiv), $\left(4-\mathrm{MeOC}_{6} \mathrm{H}_{4}\right)_{3} \mathrm{P}$ (2 equiv), TEA (3 equiv), $\mathrm{CsCl}$ ( 5 equiv). The ${ }^{1} \mathrm{H}$ NMR and HRMS spectra of pseudostellarin D are in agreement with data from the literature [37-39]. 


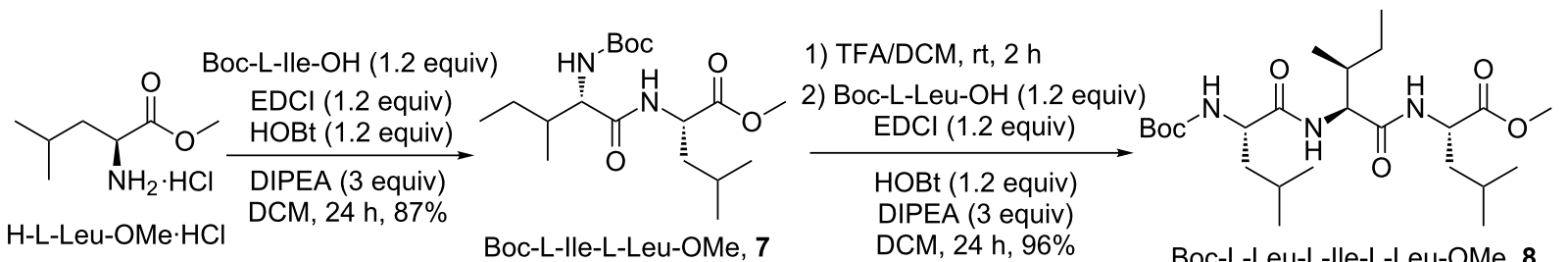
$10 \mathrm{mmol}$

1) $T F A / D C M, r t, 2 \mathrm{~h}$

2) Boc-L-Pro-OH (1.2 equiv) $N^{\prime}$ Boc EDCl (1.2 equiv) HOBt (1.2 equiv) DIPEA ( 3 equiv) DCM, 24 h, 93\%

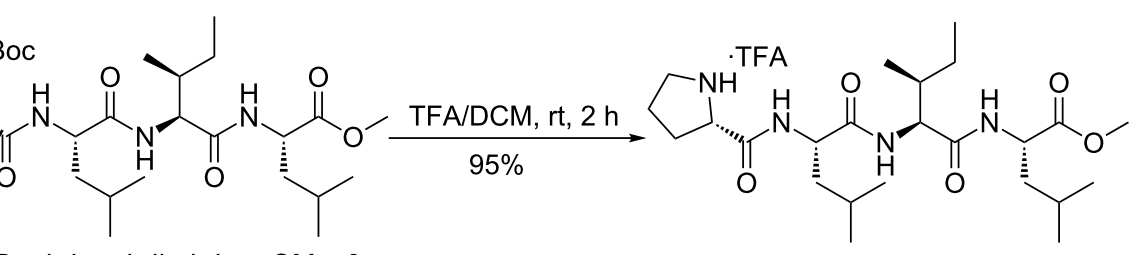

Boc-L-Pro-L-Leu-L-Ile-L-Leu-OMe, 9

TFA·HN-L-Pro-L-Leu-L-Ile-L-Leu-OMe, 10

\section{Boc-Gly-OH (1.0 equiv) FPID (1.2 equiv)}

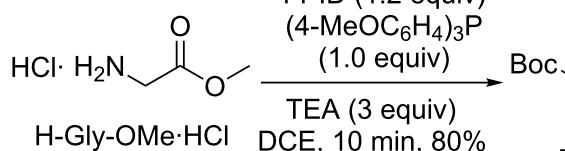
$10 \mathrm{mmol}$<smiles>CNCC(=O)NCC(=O)OC</smiles>

1) $\mathrm{LiOH} \cdot \mathrm{H}_{2} \mathrm{O}$ (2 equiv)

$\mathrm{THF} / \mathrm{H}_{2} \mathrm{O}$, rt, $1 \mathrm{~h}$

2) $\mathrm{H}-\mathrm{L}-\mathrm{Tyr}-\mathrm{OMe} \cdot \mathrm{HCl}$ FPID (1.2 equiv) Boc $\left(4-\mathrm{MeOC}_{6} \mathrm{H}_{4}\right)_{3} \mathrm{P}$ (1.0 equiv) TEA ( 3 equiv) DCE, 15 min, $73 \%$<smiles>COC(=O)[C@H](Cc1ccc(O)cc1)NC(=O)CNC(=O)CNC(=O)O</smiles>

Boc-Gly-Gly-L-Tyr-OMe, 12

$\mathrm{LiOH} \cdot \mathrm{H}_{2} \mathrm{O}$
( 2 equiv),
$\mathrm{THF} / \mathrm{H}_{2} \mathrm{O}$,

rt, 2 h, $96 \%$

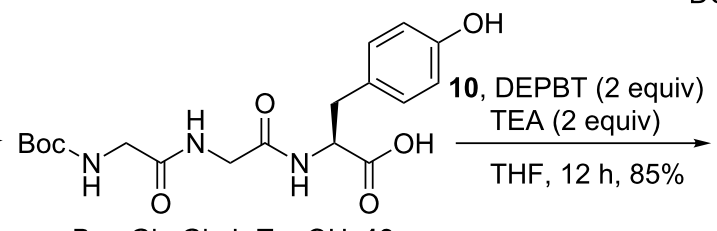

Boc-Gly-Gly-L-Tyr-OH, 13 (n)

Boc-Gly-Gly-L-Tyr-L-Pro-L-Leu-L-Ile-L-Leu-OMe, 14
1) $\mathrm{LiOH} \cdot \mathrm{H}_{2} \mathrm{O}$ (2 equiv), $\mathrm{THF} / \mathrm{H}_{2} \mathrm{O}$, rt, 5 h, $92 \%$

2) TFA/DCM, rt, 2 h, $85 \%$<smiles>CC[C@H](C)[C@H](NC(=O)[C@H](CC(C)O)NC(=O)C1CCCN1C(=O)[C@H](Cc1ccc(O)cc1)NC(=O)CNC(=O)CN)C(=O)N[C@@H](CC(C)C)C(=O)O</smiles>

TFA· ${ }_{2} \mathrm{~N}$-Gly-Gly-L-Tyr-L-Pro-L-Leu-L-Ile-L-Leu-OH, 2

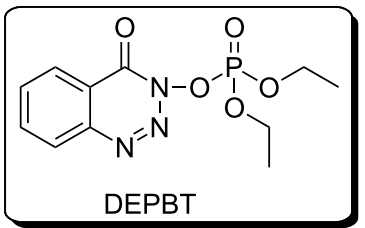

DEPBT

Scheme 5: Preparation of the precursor of pseudostellarin D.

Table 2: Optimization of cyclization of linear heptapeptide 2. $^{\text {a }}$

FPID (x equiv)

TFA-H-Gly-Gly-Tyr-Pro-Leu-lle-Leu-OH

2

$\stackrel{\left(4-\mathrm{MeOC}_{6} \mathrm{H}_{4}\right)_{3} \mathrm{P}(\mathrm{x} \text { equiv) }}{\mathrm{TEA}(3 \text { equiv) }}$
DMF, $0{ }^{\circ} \mathrm{C}$ to rt, time

cyclo(Gly-Gly-Tyr-Pro-Leu-lle-Leu)

pseudostellarin D

\begin{tabular}{|c|c|c|c|c|c|}
\hline entry & $\mathrm{x}$ equiv & additive & atmosphere & time & yield (\%) \\
\hline 1 & 1.2 & - & air & $10 \mathrm{~h}$ & $<18$ \\
\hline $2^{b}$ & 1.2 & - & air & $10 \mathrm{~h}$ & $<15$ \\
\hline 3 & 1.2 & - & air & $24 \mathrm{~h}$ & $<23$ \\
\hline $4^{b}$ & 1.2 & - & air & $24 \mathrm{~h}$ & $<20$ \\
\hline 5 & 1.2 & - & $\mathrm{N}_{2}$ & $24 \mathrm{~h}$ & $<27$ \\
\hline
\end{tabular}




\begin{tabular}{|c|c|c|c|c|c|}
\hline $6^{c}$ & 2.0 & - & $\mathrm{N}_{2}$ & $24 \mathrm{~h}$ & n.d. \\
\hline 7 & 2.0 & - & $\mathrm{N}_{2}$ & $24 \mathrm{~h}$ & 33 (NMR) \\
\hline $8^{d}$ & 2.0 & $\mathrm{CsCl}$ (5 equiv) & $\mathrm{N}_{2}$ & $24 \mathrm{~h}$ & 44 (NMR) \\
\hline $9^{d}$ & 2.0 & $\mathrm{NaCl}$ (5 equiv) & $\mathrm{N}_{2}$ & $24 \mathrm{~h}$ & 42 (NMR) \\
\hline $10^{d}$ & 2.0 & $\mathrm{LiCl}$ (5 equiv) & $\mathrm{N}_{2}$ & $24 \mathrm{~h}$ & 28 (NMR) \\
\hline $11^{d}$ & 2.0 & $\mathrm{KCl}$ (5 equiv) & $\mathrm{N}_{2}$ & $24 \mathrm{~h}$ & 40 (NMR) \\
\hline
\end{tabular}

aConditions: performed with $2(0.05 \mathrm{mmol})$, TEA $(0.15 \mathrm{mmol})$, DMF $(50 \mathrm{~mL})$. Unless otherwise mentioned, the adding sequence of TEA and FPID/(4$\left.\mathrm{MeOC}_{6} \mathrm{H}_{4}\right)_{3} \mathrm{P}$ was adding TEA first and FPID/(4-MeOC $\left.{ }_{6} \mathrm{H}_{4}\right)_{3} \mathrm{P} 5$ minutes later. " $x$ equiv" meant the equivalents of FPID and $\left(4-\mathrm{MeOC}_{6} \mathrm{H}_{4}\right)_{3} \mathrm{P}$. The NMR yield was calculated by adding $\mathrm{CH}_{2} \mathrm{ClBr}$ as internal standard substance. ${ }^{b}$ Adding $\mathrm{FPID} /\left(4-\mathrm{MeOC}_{6} \mathrm{H}_{4}\right)_{3} \mathrm{P}$ first and TEA 5 minutes later. ${ }^{\mathrm{C}} 2$ was dissolved in $2 \mathrm{~mL}$ of DMF and added portionwise to the reaction system within $2 \mathrm{~h}$. ${ }^{\mathrm{d}}$ Metal chloride was dissolved in $0.33 \mathrm{~mL}$ of $\mathrm{H}_{2} \mathrm{O}$ and then added to the reaction.

\section{Conclusion}

The system of the hypervalent iodine(III) reagent FPID and $\left(4-\mathrm{MeOC}_{6} \mathrm{H}_{4}\right)_{3} \mathrm{P}$ can be applied to the solid-phase peptide synthesis because four bioactive peptides were smoothly obtained including the precursor 2 of cyclic peptide pseudostellarin D. Moreover, we have also successfully synthesized the bioactive cyclic heptapeptide pseudostellarin D using this system. Notably, FPID can be easily regenerated after peptide coupling reaction in SPPS. These results, along with the successful use of the FPID/(4- $\left.\mathrm{MeOC}_{6} \mathrm{H}_{4}\right)_{3} \mathrm{P}$ system in the solution-phase linear peptide synthesis [29], show its potential in the practical application in peptide synthesis.

\section{Supporting Information}

\section{Supporting Information File 1}

Experimental procedures and characterization data of all products, copies of ${ }^{1} \mathrm{H},{ }^{13} \mathrm{C}$, HPLC, HRMS spectra of some compounds.

[https://www.beilstein-journals.org/bjoc/content/ supplementary/1860-5397-14-97-S1.pdf]

\section{Acknowledgements}

This work was financially supported by National Key R\&D Program of China (2017YFD020030202), The National Natural Science Foundation of China (21472094, 21172110, 21421062) and The Tianjin Natural Science Foundation (17JCYBJC20300). We are grateful to MS. Bo Sun for the preliminary investigation of this project.

\section{References}

1. Valeur, E.; Bradley, M. Chem. Soc. Rev. 2009, 38, 606-631. doi:10.1039/b701677h

2. El-Faham, A.; Albericio, F. Chem. Rev. 2011, 111, 6557-6602. doi:10.1021/cr100048w

3. Al-Warhi, T. I.; Al-Hazimi, H. M. A.; El-Faham, A. J. Saudi Chem. Soc. 2012, 16, 97-116. doi:10.1016/j.jscs.2010.12.006
4. Prasad, K. V. S. R. G.; Bharathi, K.; Haseena Banu, B. Int. J. Pharm. Sci. Rev. Res. 2011, 8, 108-119.

5. Dunetz, J. R.; Magano, J.; Weisenburger, G. A. Org. Process Res. Dev. 2016, 20, 140-177. doi:10.1021/op500305s

6. Yang, J.; Zhao, J. Sci. China: Chem. 2018, 61, 97-112. doi:10.1007/s11426-017-9056-5

7. Sheehan, J. C.; Hess, G. P. J. Am. Chem. Soc. 1955, 77, 1067-1068. doi:10.1021/ja01609a099

8. Gawne, G.; Kenner, G. W.; Sheppard, R. C. J. Am. Chem. Soc. 1969, 91, 5669-5671. doi:10.1021/ja01048a057

9. Carpino, L. A.; Henklein, P.; Foxman, B. M.; Abdelmoty, I.; Costisella, B.; Wray, V.; Domke, T.; El-Faham, A.; Mügge, C. J. Org. Chem. 2001, 66, 5245-5247. doi:10.1021/jo001616+

10. Constable, D. J. C.; Dunn, P. J.; Hayler, J. D.; Humphrey, G. R.; Leazer, J. L., Jr.; Linderman, R. J.; Lorenz, K.; Manley, J.; Pearlman, B. A.; Wells, A.; Zaks, A.; Zhang, T. Y. Green Chem. 2007, 9, 411-420. doi:10.1039/b703488c

11. Zhdankin, V. V. Hypervalent lodine Chemistry: Preparation, Structure, and Synthetic Applications of Polyvalent lodine Compounds; Wiley: New York, 2014.

12. Varvoglis, A. Hypervalent lodine in Organic Synthesis; Academic Press: London, 1997.

13. Yoshimura, A.; Zhdankin, V. V. Chem. Rev. 2016, 116, 3328-3435. doi:10.1021/acs.chemrev.5b00547

14. Zhdankin, V. V.; Stang, P. J. Chem. Rev. 2008, 108, 5299-5358. doi:10.1021/cr800332c

15. Zhdankin, V. V.; Stang, P. J. Chem. Rev. 2002, 102, 2523-2584. doi:10.1021/cr010003+

16. Singh, F. V.; Wirth, T. Chem. - Asian J. 2014, 9, 950-971. doi:10.1002/asia.201301582

17. Brown, M.; Farid, U.; Wirth, T. Synlett 2013, 24, 424-431. doi:10.1055/s-0032-1318103

18. Wirth, T. Angew. Chem., Int. Ed. 2005, 44, 3656-3665. doi:10.1002/anie.200500115

19. Li, Y.; Hari, D. P.; Vita, M. V.; Waser, J. Angew. Chem., Int. Ed. 2016, 55, 4436-4454. doi:10.1002/anie.201509073

20. Brand, J. P.; González, D. F.; Nicolai, S. F.; Nicolai, S.; Waser, J. Chem. Commun. 2011, 47, 102-115. doi:10.1039/c0cc02265a

21. Charpentier, J.; Früh, N.; Togni, A. Chem. Rev. 2015, 115, 650-682. doi:10.1021/cr500223h

22. Dohi, T.; Kita, Y. Chem. Commun. 2009, 2073-2085. doi:10.1039/b821747e

23. Duan, Y.; Jiang, S.; Han, Y.; Sun, B.; Zhang, C. Chin. J. Org. Chem. 2016, 36, 1973-1984. 
24. Zhang, X.; Cong, Y.; Lin, G.; Guo, X.; Cao, Y.; Lei, K.; Du, Y. Chin. J. Org. Chem. 2016, 36, 2513-2529.

25. Chen, J.; Qu, H.-M.; Peng, J.; Chen, C. Chin. J. Org. Chem. 2015, 35, 937-946.

26. Duschek, A.; Kirsch, S. F. Angew. Chem., Int. Ed. 2011, 50, 1524-1552. doi:10.1002/anie.201000873

27. Merritt, E. A.; Olofsson, B. Synthesis 2011, 517-538. doi:10.1055/s-0030-1258328

28. Tian, J.; Gao, W.-C.; Zhou, D.-M.; Zhang, C. Org. Lett. 2012, 14, 3020-3023. doi:10.1021/ol301085v

29. Zhang, C.; Liu, S.-S.; Sun, B.; Tian, J. Org. Lett. 2015, 17, 4106-4109. doi:10.1021/acs.orglett.5b02045

30. Merrifield, R. B. J. Am. Chem. Soc. 1963, 85, 2149-2154. doi:10.1021/ja00897a025

31. Behrendt, R.; White, P.; Offer, J. J. Pept. Sci. 2016, 22, 4-27. doi:10.1002/psc.2836

32. Dawson, P. E.; Muir, T. W.; Clark-Lewis, I.; Kent, S. B. Science 1994, 266, 776-779. doi:10.1126/science.7973629

33. Li, X.; Lam, H. Y.; Zhang, Y.; Chan, C. K. Org. Lett. 2010, 12, 1724-1727. doi:10.1021/ol1003109

34. Hughes, J.; Smith, T. W.; Kosterlitz, H. W.; Fothergill, L. A.; Morgan, B. A.; Morris, H. R. Nature 1975, 258, 577-579. doi:10.1038/258577a0

35. Hughes, J. Brain Res. 1975, 88, 295-308. doi:10.1016/0006-8993(75)90391-1

36. Naot, D.; Cornish, J. Bone 2008, 43, 813-818. doi:10.1016/j.bone.2008.07.003

37. Morita, H.; Kayashita, T.; Kobata, H.; Gonda, A.; Takeya, K.; Itokawa, H. Tetrahedron 1994, 50, 9975-9982. doi:10.1016/S0040-4020(01)89612-5

38. Himaja, M.; Harish Kumar, K.; Ramana, M. V.; Belagali, S. L. Eur. J. Med. Chem. 1999, 34, 525-529. doi:10.1016/S0223-5234(99)80101-9

39. Agrigento, P.; Albericio, F.; Chamoin, S.; Dacquignies, I.; Koc, H.; Eberle, M. Org. Lett. 2014, 16, 3922-3925. doi:10.1021/ol501669n

40. Ariyoshi, Y. Trends Food Sci. Technol. 1993, 4, 139-144. doi:10.1016/0924-2244(93)90033-7

41. Wanasundara, P. K. J. P. D.; Ross, A. R. S.; Amarowicz, R.; Ambrose, S. J.; Pegg, R. B.; Shand, P. J. J. Agric. Food Chem. 2002, 50, 6981-6988. doi:10.1021/jf025592e

42. Guang, C.; Phillips, R. D. J. Agric. Food Chem. 2009, 57, 5113-5120. doi:10.1021/jf900494d

43. Zorzi, A.; Deyle, K.; Heinis, C. Curr. Opin. Chem. Biol. 2017, 38, 24-29. doi:10.1016/j.cbpa.2017.02.006

44. Sewald, N.; Jakube, H.-D. Peptides: Chemistry and Biology, 2nd ed.; Wiley-VCH: Weinheim, 2009.

45. White, C. J.; Yudin, A. K. Nat. Chem. 2011, 3, 509-524. doi:10.1038/NCHEM.1062

46. Morita, H.; Kayashita, T.; Kobata, H.; Gonda, A.; Takeya, K.; Itokawa, H. Tetrahedron 1994, 50, 6797-6804. doi:10.1016/S0040-4020(01)81333-8

47. Morita, H.; Kobata, H.; Takeya, K.; Itokawa, H. Tetrahedron Lett. 1994, 35, 3563-3564. doi:10.1016/S0040-4039(00)73238-2

48. Morita, H.; Kayashita, T.; Takeya, K.; Itokawa, H. J. Nat. Prod. 1995, 58, 943-947. doi:10.1021/np50120a021

49. Tan, N.-H.; Zou, J.; Chen, C.-X.; Zhao, S.-X. Phytochemistry 1993, 32, 1327-1330. doi:10.1016/S0031-9422(00)95114-8

50. Fan, C.-X.; Hao, X.-L.; Ye, Y.-H. Synth. Commun. 1996, 26, 1455-1460. doi:10.1080/00397919608003508
51. Ye, Y.-h.; Liu, M.; Tang, Y.-c.; Jiang, X. Chem. Commun. 2002, 532-533. doi:10.1039/b108133k

\section{License and Terms}

This is an Open Access article under the terms of the Creative Commons Attribution License (http://creativecommons.org/licenses/by/4.0), which permits unrestricted use, distribution, and reproduction in any medium, provided the original work is properly cited.

The license is subject to the Beilstein Journal of Organic Chemistry terms and conditions:

(https://www.beilstein-journals.org/bjoc)

The definitive version of this article is the electronic one which can be found at:

doi:10.3762/bjoc. 14.97 